Clive J Napier

Research Fellow and

Former Associate

Professor, Department

of Political Sciences,

College of Human

Sciences, University of

South Africa. E-mail:

napierc@mweb.co.za

Pieter Labuschagne

Professor and Former

Departmental Chair,

Department of Political

Sciences, College

of Human Sciences,

University of South Africa.

E-mail: labuspah@unisa.

ac.za

DOI: https://dx.doi.

org/10.18820/24150509/

JCH42.v2.10

ISSN 0258-2422 (Print)

ISSN 2415-0509 (Online)

Journal for Contemporary

History

2017 42(2):208-226

(C) UV/UFS

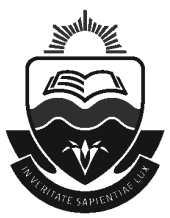

\section{POLITICAL PARTY CAUCUSES AND DEMOCRACY: CONTRADICTIO IN TERMINIS?'}

\begin{abstract}
The concept of "caucus" has historically been imbedded within practical politics and in the disciplines of political science and history. In a general sense, a caucus (also referred to as a parliamentary party) aims to reach agreement between individuals on specific matters. In parliamentary politics and at all levels of government a caucus forms an essential structure in the functioning of a political party within a legislature, being an integral part of the strategic makeup of parties from central parliament down to the local level. The leadership of political parties organise their members into groups, but individual members may also organise themselves into groups which are generally known as caucuses. In the various caucuses, general strategy, policies and the candidates to be voted for, or to be elected into office are decided and agreed upon - this, to ensure that the party demonstrates solidarity within the respective legislatures and to the outside world. The secret manner in which a party caucus operates within a supposedly transparent democracy raises a number of concerns. The question is whether such secrecy and the insistence that all party members of a caucus - particularly in parliamentary political systems - toe the party line, infringes on the diversity of interests that elected members are supposed to represent? The purpose and values of democratic representation presuppose a direct line from the individual voter(s) to the representatives in a legislature. The caucus in effect inserts a space between individuals and their respective legislatures which may require that diverse interests be sacrificed for the sake of solidarity and a common strategy. The aims of the article are to make specific reference to the South African experience to ascertain whether a caucus undermines the democratic principle of representation and is in effect a contradictio in terminis.
\end{abstract}

Keywords: Caucus; parliamentary party; political parties; politics; representative democracy.

Sleutelwoorde: Koukus; parlementêre party; politiek; politieke partye; verteenwoordigende demokrasie.

\section{INTRODUCTION}

Like many aspects of the democratic process and its accompanying institutional structures, political party caucuses

1

Contradiction in terms 
(also referred to as parliamentary parties in the United Kingdom (UK) and in countries adhering to the Westminster political system) are not well known to the general public, nor well researched or written about in the academic literature. Political party caucuses and their activities tend to be more public and diverse in the United States (US), predominantly because of their highly visible role during the nomination of presidential candidates and their activities in various legislative bodies.

An internet search for basic information on political party caucuses yielded little. A subsequent search of political science texts, biographies and autobiographies of political leaders and personalities was similarly disappointing. Most references allude to the American experience, the existence of caucuses, and the Democratic and Republican Parties' use of this means to nominate candidates for political office, or to pursue specific interests. The literature on caucuses in the Westminster system of government tends to be equally limited and much of what is written about them is obscure. Some of the more important texts are referred to below.

An explanation for the opacity of the internal activities of parliamentary parties and caucuses is largely that much of their work is conducted in secret and deliberations remain confidential. They are seen as private organisations operating alongside or outside formal governmental structures. The manifestation of caucus decisions is reflected in the positions taken by political office bearers emerging from and writing about those bodies, whose proposed strategies and tactics are adopted by their political parties in their respective legislatures.

The main purpose of this article is to explain the veil of secrecy surrounding caucuses and their functioning. Their origins, structure and functioning are examined, as is their relationship with the salient features of representative democracy. One of the fundamental underpinning questions is to determine whether caucuses undermine the democratic principle of representation, which is an essential element of representative democracy. In the discussion, reference will be made to relevant examples from the South African experience for illustrative purposes.

\section{HISTORICAL ORIGIN AND STRUCTURE}

As indicated, the literature in political science is fairly mute on the origins, structures and functioning of caucuses. The reason for the paucity of source material is probably that very little information emerges on caucuses and their internal functioning due to their secretive nature, more particularly in non-US contexts.

The available literature deals predominantly with caucuses and their presence in the American presidential system (Bruce 1988; Pinney and Serra 1999; Edelman 2013), making limited reference (Webb 2008) to the Westminster 
parliamentary parties, or those of the Australian, British Commonwealth and European countries. An early exception is CF Strong (1966) in his highly thoughtof text, Modern political constitutions. In the Westminster or parliamentary system, caucuses are mostly described as closed bodies, tasked with selecting candidates and discussing matters relating to policy and strategy pending before a legislative or other policy-making body. Little is said on the manner in which caucuses reach consensus on these matters.

The short dictionary definitions of a party caucus are similar in that they predominantly state that a caucus comprises a meeting of a legislative body (whose members belong to a particular political party), with the specific purpose of selecting candidates for a particular position, or deciding on a certain policy (American heritage dictionary 1970; Roberts 1971:27c; Laqueur 1973:77; Francis 1985; Brits 1995:44; Talbot 1998). Kotzé and Van Wyk (1988:81) describe a caucus as a meeting of a political party, or a faction of a political party, with the purpose of electing party leaders, deciding on candidates for election and/or formulating policies.

What emerges from the definitions provided are that caucuses generally operate in secret, they plan strategy and devise policy, membership is limited only to party members, and they decide on candidates for election.

The historical development of caucuses has its roots firmly imbedded in the political history of America, where from the mid- $18^{\text {th }}$ century "caucus" was used in the city of Boston to describe a meeting of the leaders of a political club or party, convened to make arrangements for elections (Bell 2008).

Ibele (1971:299) dates the origin of caucuses in the US to the 1830s, and similarly describes them as one of the structures used to nominate candidates for public office. In more contemporary US politics the concept has largely been superseded by the party convention, although in several states the caucus is still used in combination with a direct primary election process in a presidential election year to elect delegates to the respective parties' national conventions. In these caucuses the residents and party members of each state elect delegates from the Democratic or Republican Party to the respective state conventions, from where their candidate for the presidential election is elected ( $T$ he free dictionary).

In the American legislatures, city, state and federal caucuses denote the assembly of party members in what are called "conferences" or "forums". These caucuses, which are convened for special or limited purposes, comprise members from larger caucuses or sections of legislatures, such as the "Black Caucus" (Pinney and Serra 1999; Edelman 2013). Many additional caucuses in the US Congress exist predominantly to pursue factional or sectional interests (United States House of Representatives). A recent example is the creation in the US Congress of a special caucus or formation referred to 
as the "Freedom Caucus", consisting of about 40 Republican members out of a total 247 whose aim is to pursue a partisan agenda (Anon. 2015).

In the US, unlike Westminster systems of government, the role of the elected party leadership, the caucuses, and the committees involved in the management of legislative business has varied (and continues to vary considerably) from one state legislative chamber to another. This variation depends, in part, on the majority party's percentage of seats and on the size of the chamber. The party caucus is less central in chambers which are large, or have dominant parties. Where the majority party caucus is central, legislators express greater satisfaction with committee decisions than with caucus decisions. This may be explained by an accommodating committee assignment process which allows legislators to build up communities of interest, and by the fact that committees are normally smaller than caucuses, allowing individual members to have greater input (Francis 1985).

Within the main political parties in the UK (Labour, Conservative and Liberal Democrat) certain groupings may exist: one example is the Conservative and Unionist Members Committee, popularly known as the 1922 Committee. The other, which both Labour and Conservative Parties have, is a policy committee system organised around subject areas which roughly correspond to those of government departments (The British Parliament 1968:17-18).

Further, these parliamentary parties (Conservative, Labour and Liberal Democrat) play a role in electing their leaders, often in combination with grassroots party membership. This was the case when Theresa May replaced David Cameron as leader of the Conservative Party in 2016, and Labour leader Jeremy Corbyn fended off a leadership challenge in the same year.

In the French political system parliamentary caucuses are referred to as "groups". Duverger, in his 1972 book, Political parties: Their organization and activity in the modern state, devotes a great deal of attention to caucuses. Duverger conceptualises a political party not as a community, but as a collection of communities and distinguishes four main elements: the caucus, the branch, the cell and the militia. The caucus is of concern here. According to Duverger (1972:18), it could well be called a committee, clique, or coterie, but the English term is most often used. He lists several characteristics which still apply to present-day caucuses: in the case of European and Commonwealth countries, political party caucuses generally comprise elected members of a particular legislature, but may also consist of registered party members constituted as elective bodies, or non-elected representatives and ordinary party members (in the case of the US). A caucus mostly meets under the chairmanship of a caucus chairperson - a position usually elected by members of that caucus. In most cases, caucuses have a set of rules regulating their activities, although these are not readily available to voters or supporters of the political party in 
question. This secrecy contributes to a degree of skepticism regarding the nature of caucuses.

Duverger (1972:18) explains that caucuses are limited in nature and, thus, consist of a small number of members. There is no concerted effort to propagate messages to extend their recruitment, or to admit more members. The group is closed, and membership is achieved through cooption or formal nomination. Basically, the closed nature of caucuses can be ascribed to their strength of not being dependent on the number of members, but on their quality.

An additional feature of caucuses is that they function within a geographical area; in the case of the American political system they reach the peak of their activity at election time (Duverger 1972:18). Before the suffrage was extended to the masses, parties were essentially federations of caucuses, but after this change came about, parties retained their caucuses in various shapes and forms.

On balance, the caucus systems in many parts of the world reflect their strong historical link to the Westminster parliamentary system. As a result, caucuses have developed over time alongside the historical development of political parties. The British Westminster parliamentary system, as the mater parliament of all similar systems, gave birth to the political party - and the caucus developed in tandem with the political party (Ball 1992:115). The South African caucus system followed the Westminster model and, as a result, developed along similar lines.

Although a caucus is mostly associated with the Westminster parliamentary system, the American presidential system has developed its own permutation. The establishment of caucuses in the various American states mainly occurs with a view to electing a future president, while the narrower usage of a caucus for election purposes has provided the concept with a totally different meaning (see below).

A broad distinction can therefore be made between presidential and parliamentary systems of government: in the American presidential system a caucus is a meeting of local members of a political party, convening to select delegates to a convention, or register a preference for one of the candidates running for office. In a parliamentary system, however, a caucus is a closed meeting of party members within a legislative body whose role is to decide on questions of policy or leadership (Heywood 2009:402).

\section{THE SOUTH AFRICAN ORIGIN OF THE CAUCUS}

Venter (1989) and Venter and Johnston (1991), who have dealt with the historical development of the caucus system in South Africa, point out that it was in use in the pre-1910 old Cape Parliament before being extended to the government's institutional system up to and into the post-1994 Parliament. Since 
the traditions of the Westminster model were mirrored in both the pre- and post1910 governmental systems, the party caucus system was also adopted. The use of the caucus as a decision-making mechanism continues to operate in the post-apartheid South African democratic parliamentary system. To illustrate their importance, their meeting schedules have been formalised and they meet on specific days of the week as determined by their respective party rules.

Venter (1989:55-56) defines the role of the caucus system in the pre-1994 South African Parliament as a platform used by political parties to clandestinely and tactically coordinate strategy before a parliamentary session.

In general, party caucuses were not regarded as policy-making instruments, but as an opportunity to debate party strategy. They also afforded the leadership of the party a chance to inform members of major policy decisions. Although party caucus deliberations are confidential and little of what transpires is known to the public, depending on the traditions of the party concerned, members could speak their mind. Thus, caucuses present an opportunity for back-benchers to voice their opinions and question party leaders (Jackson and Jackson 2009:268) - a procedure which also applies to South Africa. Once a decision is reached, members close ranks and speak with one voice. Because the functioning of South African party caucuses is limited to parliamentary affairs rather than party affairs, they are not seen in legislation as a functioning, formal body of a political party; thus, their existence and roles were hardly mentioned in their respective party constitutions (Venter 1989:55-56).

Venter and Johnston (1991) note that, besides the formal rules according to which legislatures operate, there is an informal dynamic attached to most legislatures. In political systems where legislators are elected in accordance with a constituency system, legislators are elected in their personal capacities, but are members of a political party. In a proportionally based electoral system where representatives are not elected by wards or constituencies, legislators can only be party members. In order to promote a particular view in a legislature, political parties form caucuses for this purpose. Caucus members are expected to adhere to the party policy line; should they not do so, they may be excluded from the caucus and the party itself (Venter and Johnston 1991:78-79).

In the post-1994 constitutional period in South Africa, a shift appeared in the way political parties operate, with all members of the party in a particular legislature now required to be members of their respective caucuses. When members congregate to participate in caucus meetings, they tend to speak of attending caucus, or engaging in "caucusing". Contemporary South African political parties operate caucus systems in all spheres of government - central, provincial and local - in view of the enfranchisement of the entire voting population following the 1994 democratic election. With the total number of registered voters at more than 25 million in 2014, up from more than 18 million 
in 1999 (SAIRR 2016:803), this suggests an incentive for political parties to organise internally.

In the minds of the public, the functioning of a caucus has progressively obtained a meaning and an association with an action (or actions) that is mostly regarded as negative or underhand. In general terms, the public often associates a caucus with the secret and private actions of a group of people who are conspiring to take a preemptive position on a policy position, tactic or strategy.

\section{CAUCUSES - THEIR FUNCTIONING IN A DEMOCRACY}

The confidential or secretive nature and the inclusivity of deliberations are some of the critical characteristics of any caucus. The fundamental question is this: Is such secrecy compatible with the concept of representative democracy ${ }^{2}$ within the legislative and executive spheres of government? With reference to contemporary examples, one might well ask: Is the secretive and closed nature of a caucus incompatible with the transparent and open nature of the ideals of a democracy and the values underpinning an open society (Du Plessis 2005:842)?

Strong (1966:192), an early proponent of political democracy, refers to the, "evil influence of the party caucus". Strong (1966:188-190) situates his condemnation within the extension of the franchise and the widening of the electoral area, now characteristic of many constitutional states. An enlarged electoral area tends to destroy personal contact between a party candidate and a constituent, and may multiply the number of constituents and sentiments on issues. Further, Strong (1966:192) argues that with the enlargement of the electoral area and the remuneration of legislators has come a widening of the potential choice of legislators and greater independence for them - hence the suggestion that legislators are more likely to have to fall in line with caucus rules and forsake some of their independence and idealism.

Altundal (2016:11) emphasises the link between the electorate and decision makers as being pivotal in any democracy, as it guarantees that the effective power to govern lies in the hands of democratically elected representatives who have to ensure that the will of the electorate is not frustrated. In light of this elevated position, the question should be posed whether the intrinsic functioning of a caucus, in general, strengthens or undermines the ideals and values of direct representation within the ambit of democratic participation?

The ideal that Altundal (2016:11) articulates does, however, need to be balanced against the good of the party, as well as strategic considerations. The position of a caucus within a political institutional framework, or within the structural make-up of the modern democratic state, is that it provides a pivotal

2 Representative democracy entails the idea that all individuals should have equal access to public policy by choosing individuals (in government) to represent them and to make policies between elections. 
point for all political parties from which to operate. A caucus could be described as similar to the central point of a spider's web which controls every aspect of the strategy of political parties in legislatures. In contemporary South Africa, the various political parties at all three levels of government (parliamentary, provincial and local) have organised themselves into caucuses for functional and strategic reasons.

The caucus is undoubtedly the strategic engine room of any political party (but more so for larger political parties because of their growth and increasingly impersonal nature) and serves as the critical, strategic platform from which to find common ground on strategies, as well as to nominate and elect members.

Organising political parties in a cohesive unit, such as a caucus, is easily understandable from a strategic point of view where solidarity is important. Enforcing a unified and common strategy is not only essential for all political parties, but is central for success within the parliamentary system in terms of the interaction with opposition parties. It is crucial for political parties and their leaders to ensure that their fellow party members (representatives in parliament, or at other levels of government) adhere to party policy. For strategic reasons, it is important for all political parties to present a unified front to their respective oppositions, and to win internal legislative divisions or votes when called out on contentious issues.

The importance of a caucus is its cohesiveness and its pursuance of a common strategy. By the same token, in specific situations it is important that strategies be devised in a clandestine manner to allow for maximum impact. Although the secretive nature of hidden strategies may undermine the lofty ideals of representative democracy, its practical value should also be considered in furthering party interests.

Green (2002:115), who writes on discipline within caucuses, emphasises that the central problem for American legislative parties is to enforce discipline and uniformity within their respective caucuses. In the US context, Green (2002:115) refers to this ruling as a "binding party caucus" with the authority, granted by its rules, requiring all party members to cast their votes in a particular direction. It is in the caucus in the British and other contexts where the leaders of the various political parties are able to instill discipline and, with the aid of the whips, ensure that members toe the party line (Coe 2012:115).

\section{POLITICAL PARTY CAUCUS IN THE SOUTH AFRICAN AND AFRICAN CONTEXTS}

In South Africa, political parties have employed caucuses to manage internal matters since the early part of the $20^{\text {th }}$ century. The former National Party (NP) used caucuses extensively and, as a result, they played a critically important role since the party's founding in 1914 . Within the NP the party caucus quickly 
became the nexus of party organisation, as was illustrated by the fact that new leaders were not elected at a national congress, but from within the caucus. On many occasions the "good work" of a party member in the caucus or caucus committees was rewarded by their appointment as a deputy minister, or by them being appointed to a ministerial position (Wiechers 1985:248).

When JG (Hans) Strijdom replaced Dr DF (Daniël) Malan as prime minister in 1954, the cabinet strongly protested when Malan suggested that the governorgeneral should appoint the prime minister in the hope that his choice, Klasie Havenga, would get the nod. However, the majority of his cabinet ministers strongly protested that the appointment of the new prime minister should be done by the party caucus, not the governor-general (Koorts 2013:420). The will of the caucus again prevailed in this case, rather than that of the voters or the governor-general.

Venter (1989:56) emphasises the importance that political parties attached from the outset to the role of a caucus in South African parliamentary politics by referring to the example of the former State President and leader of the NP, PW Botha (1978-1989). During his term in office, Botha liberally used his provincial and parliamentary caucuses to inform members of policy changes. However, in the end the status of the caucus worked against him. In 1989, as Botha's health was failing, he made the decision to step down as leader of the NP, but decided to remain in his other role as state president. His absence and subsequent inability to continue to dominate the caucus were used against him and led to his eventual removal as president (De Klerk 1998:112).

In South Africa the organisational structure of parties has hardly changed over the years, even post-democratisation in 1994. Most parties still have a decentralised provincial or regional organisational structure, each with its separate annual congresses, caucuses and branches. Political party structures generally allow members to make policy inputs at a lower level, which eventually serve at the provincial and the national levels. However, the rise in importance of the caucus - especially during the NP's dominance in the late 1970s - had a negative effect on the status of congresses. It was a sign of elitism that developed with leaders who began to ignore annual congresses, but rather used caucuses as platforms to legitimise political changes and achieve consensus on policy changes. Venter (1989:175) cites Schrire (1979), who was also of the opinion that the influence of the caucus on policy became more overt during the last few decades of NP rule, impacting on the status of party congresses as important policy decision makers. During this period, the NP Caucus would meet weekly during parliamentary sessions to receive explanations for policy decided by cabinet and to discuss tactics aimed at giving effect to the policy in parliament (Thompson and Prior 1982:172).

Despite the value attached to the status of the modern caucus, it was not always in a position to gloss over differences, or to allow members to reappear 
united after a caucus meeting. If a disagreement in a party caucus meeting was too severe and not all members were amenable to changes or policy positions, disagreements could spill over and split a caucus. When Dr Andries Treurnicht was elected leader of the NP in the former Transvaal Province, he became a dominant player within the party caucus, owing to his membership of the provincial NP stronghold. Treurnicht wielded a great deal of influence and authority within the caucus. Because of his ideological leanings, he found it progressively more difficult to toe the party line and to agree to policy changes. When PW Botha introduced reforms in the early 1980s which lead to the new 1983 Constitution and moderate political change, this created tension within the NP caucus. During a subsequent meeting, Treurnicht tabled a vote of no confidence in Botha and lost. He then resigned from the NP and formed the Conservative Party, which rapidly captured over a third of the Afrikaner vote (Johnson 2004:178).

Given the strong discipline amongst South African parties, the example of Treurnicht's "rebellion" is an exception. In the modern post-apartheid era the breakaway of the Congress of the People (COPE) from the African National Congress (ANC) in 2010 is the only other prominent and substantial split to have occurred. It did not, however, take place in the caucus, but in the National Executive Committee (NEC) of the party which overlapped with caucus membership. The reality is that opposition or caucus rebellions are a rare, rather than a regular feature of local politics. As a high premium is placed on solidarity and cohesion, substantial splits within parties are rare. The notion of an internal revolt - which is strong within the British parliamentary party system with its rebel back-benchers - is weak within the South African political system.

A rare exception of a caucus rebellion in the wider African context was a recent complaint made in June 2016 by Ugandan legislators against the stranglehold that their caucus held over them. Members of the National Resistance Movement (NRM) decried the tendency of political parties to dictate to them what positions to take in parliament on topical issues. "The Members of Parliament said it was common for party whips and party leadership to ignore their ideas in the political party caucuses", and as one of the members of parliament stated, "we represent constituents who may need us to advance issues that are not necessarily in tandem with our party positions and so we need that freedom" (Parliament of Uganda s.a.). 


\section{POLITICAL PARTY CAUCUSES IN POST-1994 DEMOCRATIC SOUTH AFRICA - THE RULING PARTY AND THE OFFICIAL OPPOSITION}

\subsection{The African National Congress (ANC)}

The ruling African National Party (ANC) strongly subscribes to the concept of a caucus, although officially it reflects a measure of negativity towards this entity. The ANC webpage (ANC s.a.) emphasizes and outlines the importance of a caucus, but with specific reservations. The general reference on the website to its caucus is that its overarching task is to keep the members of parliament (MPs) of each political formation informed about the parliamentary programme, and to enable MPs to discuss and agree on the approach the party will take on all matters on the agenda. However, in the outline on the website there are clear signs of negativity towards caucuses, with sentiments expressed that the concept does not derive from ANC organisational experience or culture, but was taken from parliamentary practices the ANC found amongst the remnants of the former Apartheid Parliament. In the case of the ruling party, the NEC plays a major role in decision making, and it would appear that its functioning overlaps with that of the parliamentary caucus. The extent of that overlap is, however, not clear.

As is the case with most political parties, in biographies and autobiographies only occasional reference is made to caucuses. One such reference is by Andrew Feinstein (2007), a former ANC member of the Provincial Legislature (MPL) in Gauteng, and later an MP. According to Feinstein (2007:44), "weekly caucus meetings tended to be long-winded, stultifying affairs, dealing with the minutiae of the legislative, political and administrative functioning of the party in the Legislature", whereas the meeting of 24 November 1994 was, "the rare exception, people felt quite passionate about the naming issue". Here, Feinstein (2007) was referring to the proceedings in the ANC provincial caucus in what was later to be renamed the Gauteng Provincial Legislature, which played a deciding role in renaming the Pretoria Witwatersrand Vaal Triangle (PWV) as "Gauteng", in preference to "Egoli".

Following the 1999 election and Feinstein's arrival in the national assembly, he spoke of the, "impassioned caucus discussions" (Feinstein 2007:75) and having to sit, "through a number of ANC caucuses" with President Nelson Mandela present. During the Mandela years, "the caucus room had resonated with sharp debate and discussion, passionate argument and profound polemic" (Feinstein 2007:123), whereas in the subsequent Mbeki years, "the caucus reflected a more disciplined, choreographed and constrained party". The parliamentary caucus was the forum in which former President Thabo Mbeki 
stated, in September 2000, his highly controversial view that HIV did not necessarily cause Aids (Feinstein 2007:125).

Despite the public importance that the ANC attached to caucuses, information regarding their understanding of its functioning was not available. An effort by the authors of this article to obtain information from the ruling party (the largest party post the 1994 election) on its caucus or caucus rules was unsuccessful.

\subsection{The Democratic Alliance (DA)}

The official opposition, the Democratic Alliance (DA), effectively employed the caucus as an organisational and strategic weapon since its founding in the year 2000. As the second-largest parliamentary party in the South African context, the DA allowed open access to its caucus rules for three spheres of government. Each document sets out in fairly specific detail the structuring and functioning of each caucus, suggesting the important role it plays in the work of the party. Caucus office bearers include the parliamentary leader of the National Council of Provinces (NCOP) council chair, chief whip, deputy chief whip, treasurer and all elected members.

The purpose of the DA's parliamentary caucus is to promote the vision and policies of the party, and to plan and execute the party's strategy in parliament. Moreover, the caucus document states that attendance at caucus meetings is compulsory, and that it is the duty of all members to be present and vote in their respective house of parliament - be it the national assembly or the NCOP. Further, the DA parliamentary caucus rules document states that all members are bound by decisions approved by a simple majority of caucus members, and no member may differ publicly from the decisions taken. Caucus proceedings, including discussions and decisions, are confidential and any disclosure of information may only be done by a member appointed and sanctioned by the parliamentary leader, caucus chair or chief whip. The caucus rules are binding on all parliamentary caucuses (present and future), and implicit in this is the fact that they are binding on all members of that caucus (DA 2011).

The DA Caucus in the national assembly has (like on occasion with the ANC) played a fairly public role on critical matters. One such instance was the election of a new parliamentary leader in the middle of the 2009-2014 parliamentary term. Two candidates fiercely contested the leadership battle for the support of caucus members. The incumbent leader, Athol Trollip, had as his opponent a first-term MP, Lindiwe Mazibuko. The contest for a majority of the 80 caucus members - which would normally be a subdued, internal matter receiving little attention in the media - was elevated by the intervention of the leader of the party at the time, Helen Zille. Despite not being a member of the caucus, Zille backed Mazibuko to the annoyance of many. In doing so, she put the spotlight on the status of the parliamentary caucus as an important strategic 
decision-making forum, shaping the image of the party amongst the electorate (Zille 2016:344-350).

The rules and functioning of the DA Caucus in the Gauteng Legislature are similar to those of the parliamentary party. The rules for this caucus provide for a similar leadership and management hierarchy as for the parliamentary party. Members should subscribe to the policies, values, principles and constitution of the DA, and should exercise, "loyalty and confidentiality". As with the parliamentary party, each member of the caucus is bound by the decisions of the caucus. Moreover, the caucus has a policy-making role in line with the policy laid down by the party at national and provincial levels (DA s.a.).

As the official opposition in the Tshwane Metropolitan Municipal Council (TMMC) prior to the 3 August 2016 local government election when it formed a minority government, the DA operated a formal caucus system for its 82 members - similar to that at the parliamentary and provincial levels. Half of the members are elected on a ward basis and the remainder on the basis of a proportional representation list. By contrast, parliamentary and provincial caucus members are all elected on a proportional representation basis. In terms of a set of rules drawn up by the DA members of the party represented in the council, all members are obliged to join a caucus and attend its regular monthly meetings. Members were sworn to secrecy regarding matters addressed in the caucus (Millar 2015).

Caucus members operated in an adversarial party system in the council and under a hierarchy of laws that governed the conduct of local government councillors. According to the caucus chairman, the caucus structure featured a management committee consisting of a leader of caucus, a chairperson, a chief whip and a number of whips (i.e., members who performed administrative tasks similar to those of the parliamentary and provincial caucuses). The caucus also featured a number of portfolio committees organised to correspond with those in the larger council itself, headed by shadow members of the Mayoral Committee (MMCs) (Millar 2015). The leader was elected by caucus members in terms of a prescribed party electoral process, the chief whip was appointed by the leader, and other members of the management committee were elected by caucus members.

This caucus, moreover, has multiple functions, the primary being to decide on the strategy and tactics to be employed in full council meetings and council committees. A list of speakers on particular council agenda items was decided upon before being forwarded to a programming committee of council for listing (as speakers on council items in a future meeting). Further, in caucus meetings strategy and tactics were planned, including what position to take on a particular council agenda item (e.g., to support or oppose an item, or suggest amendments). In deliberating on the position to be taken, freedom of expression was permitted. Once a position has been taken on an item, however, the caucus 
members close ranks and abide by the collective decision of the caucus. Diverging views were not entertained in public and remained within caucus bounds (Millar 2015).

Amongst the additional functions of the caucus are the following: to provide a forum for individual councillors to interact with fellow councillors on common issues relating to their respective portfolios, the constituencies and wards they represented, as well as party issues and policies. It performs a socialising and integrating role for its members and presents a learning opportunity for individuals. The caucus complements other party structures (for example, policy conferences, constituency committees and branches) by formulating policy and electing representatives, not only to formal council bodies, but also to partypolitical entities (Millar 2015).

Finally, the caucus management has an evaluative role in monitoring the performance of individual councillors in their respective roles in council. This, in turn, complements their performance outside of council (Millar 2015).

The inner workings of the Tshwane Caucus nonetheless continue to remain a mystery in view of the secrecy rule. The goal is to win debates and electoral battles in furtherance of the interests of the party.

\section{CAUCUSES AND DEMOCRACY - CONCLUDING REMARKS}

The most fundamental aspect outlined in the preceding discussion is that caucuses may frustrate the ideals of a representative democracy, and that democratic values may be sacrificed for the sake of strategic gains. If there were disagreements on policy, or on what issue to support, modify or reject, the voters who voted their representatives into office would remain none the wiser about caucus decisions, because these entities operate in secret. In some cases, members of a minority party are voted into office to represent a specific sectorial interest which may be negated because of the dominance of the majority. When members reappear from a caucus meeting, it is as a solid unit, showing a united front and creating the impression that no disunity or disagreement ever existed. The caucus, in reality, amounts to a body in which the view of the majority will prevail, while the minority will have to bow to the interests of the majority.

The precise nature of democracy and democratic rule continues to be the subject of fierce debate. In its most basic form a democracy represents the link between the ruler and the ruled. In Greek, the words demos and kratos (democracy) were combined to indicate rule by the people. The essence of the word was probably best captured by Abraham Lincoln in his 1864 Gettysburg Address where he explained that democracy is, "government of the people, government for the people and government by the people" (Heywood 2009:66). 
If a democracy is indeed government by the people, as indicated by Lincoln's dictum, then the caucus may break the direct line between voter and representative. On a theoretical level, the original message or mandate may be relinquished or watered down in favour of the majority, or bent to comply with a party's policy position on the issue.

Where the party leadership comprises members of the caucus, it is likely that the latter will follow the lead of the leadership. Where there is little or no overlap between party leadership and caucus membership, caucus decisions could diverge from party policy to take a more responsive stance towards voter interests. The alternative could also prevail where leadership within caucus is strong and takes a view out of line with individual voters and voter interests.

On a theoretical level, the caucus intrinsically and inherently obstructs and tarnishes the fundamental nature of democracy and representivity. Dahl (1989:109) in his seminal work, Democracy and its critics, wrote in 1989 on the salient features of democracy. In his analysis of a procedural democracy he states that effective participation can only exist when the following criteria have been established: effective participation, voting equality, enlightened understanding, control over the agenda and inclusiveness. Dahl (1989:109) further argues that, throughout the process of making binding decisions, citizens ought to have an equal and adequate opportunity to endorse one outcome rather than another. He emphasises the voters'/citizens' control over the agenda and that they should determine for themselves what they wish to decide on, stressing that the process would not be democratic if someone else were to determine what is important.

In the broader ambit of the theories of representation the category of the doctrine of a "mandate" features prominently. Within the theory of the doctrine of mandate its salient features come very close to describing the ideal relationship within society of an indirect (representative) democracy. The doctrine of mandate is based on the idea that, in winning an election, a party gains a popular mandate that authorises it to carry out whatever policies or programmes it outlined during its election campaign. The doctrine of mandate imposes some kind of meaning on the election result, "as a way to keep politicians to their word" (Heywood 2009:209).

The important question is how the concept of a caucus is compatible with, or aligned to, the values of representivity as the ideal type of democracy, or with the theory or doctrine of mandate? Obviously, there is a problem of compatibility and alignment which conflicts with the essential nature and inner working of a caucus. The proceedings in parliament, the hierarchy in respect of the urgency of matters, the type of issues to be discussed, and how members will vote, are determined in a party caucus. The caucus is thus a filter, an additional "chamber" between the voter and the representative in parliament.

The juxta-positioning of a caucus within the parliamentary system actually, in some cases, frustrates the ideals of a clear line of communication between 
the initial view of the voter and what transpires in parliament. In most cases it is not a problem, but it is conceivable that there will be instances where minority views do not prevail. The primary purpose of a caucus is essentially to function as a filter to refine opposing views into a single, unified position. The caucus predetermines the unified view, and it is conceivable that the popular mandate on some issues with minority support may be sacrificed for the greater good of the party.

McHenry (2008:41) summarises the problematic aspect of a caucus as follows, "[The caucus] involves a radical change from the methods under which responsible government has hitherto conducted. Parliament instead of being an area of open discussion will be turned into an office for simply registering decision arrived at in a secret enclave."

It is evident that the caucus system potentially has the ability to undermine the theoretical ethos of democratic representivity. If the original mandate of the voters needs to be sifted through the strategic filter of a caucus, it will essentially undermine the theoretical assumptions of indirect representative democracy.

The fundamental nature of a caucus is pragmatic and strategic with the sole aim of maximising party unity. Berg (1990:73) writes that the purpose of the caucus is primarily to ensure that diverse opinions unite. This is done to increase influence and with the realisation that, in unity, the power of the group will be strengthened; thus, minority views need to be sacrificed. This realisation contains a problematic aspect, because in principle it is a simple choice between two opposing and contradictory principles and values which cannot be served simultaneously.

Berg (1990:73) reiterates that this fundamental contradiction forms the fault-line representing a basic choice between the strategic advantages of a caucus and a unified position, versus the deeper fundamental values of representivity. It is one of the two goals that should be subscribed to; yet, both cannot be served. In the process of enforcing discipline and a joint position with majority support, sectional or minority views will be sacrificed for the greater good and the solidarity of the party.

It cannot be denied that caucuses in democratic political systems play an important (if not a pre-eminent) role in decision-making processes in legislatures. The answer to the question posed earlier therefore cannot be answered emphatically. The main obstacle in the way of a simple answer is the secrecy in which caucuses operate. Internal deliberations are simply not accessible and, therefore, a definitive judgement cannot be made. Moreover, the operations of caucuses vary considerably from one political system to another. The closer the caucus membership is to the political leadership and party policy, the less likely caucus decisions will diverge from voter interests. The answer to the question whether caucuses are a contradictio in terminis of democratic theory is therefore inconclusive. 


\section{LIST OF SOURCES}

African National Congress (ANC) s.a. "African National Congress parliamentary caucus", <www.anc.org.za>, accessed 5 December 2016.

Altundal, Y 2016. "Powerless duplicators of masculine politics", Journal for Labour and Social Affairs in Eastern Europe 4(1):539-561.

American heritage dictionary of the English language 1970. New York: Dell Publishing Co.

Anon. 2015. "The reasonable job caucus", Time 186(17), 4 October.

Ball, AR 1992. Modern politics and government. London: MacMillan.

Bell, JL 2008. Boston 1775 (blog), "Colonial Boston Vocabulary: caucus", 7 January, <http://boston1775.blogspot.co.za/2008/01/colonial-boston-vocabularycaucus-part.html>, accessed 2 December 2016.

Brits, JP 1995. Concise dictionary of historical and political terms. London: Penguin.

Bruce, AR 1988. "Party caucus development and the insurgent minority party in formerly one-party state legislatures", American Review of Politics 19:191-216.

Coe, S 2012. Running my life: The autobiography. London: Hodder and Stoughton.

Dahl, R 1989. Modern political analysis. New York: Prentice Hall.

De Klerk, FW 1998. The last trek and the new beginning. London: MacMillan.

Democratic Alliance (DA) s.a. Standing orders: DA Caucus, Gauteng Provincial Legislature.

Democratic Alliance (DA) 2011. Democratic Alliance parliamentary caucus rules, as approved on 17 March 2011.

Duverger, M 1972. Political parties: Their organization and activity in the modern state. London: Methuen \& Co.

Edelman, M 2013. "Congressional Black Caucus should be more inclusive", Harvard Journal of American Public Policy 2013:35-43.

Feinstein, A 2007. After the party: A personal and political journey inside the ANC. Johannesburg: Jonathan Ball. 
Francis, WL 1985. "Leadership, party caucuses, and committees in U.S. state legislatures", Legislative Studies Quarterly 10(2), May:243-257. https://doi. org/10.2307/439726

Heywood, A 2009. Politics. Palgrave: Basingstoke.

Ibele, $\mathrm{OH}$ 1971. Political Science. An introduction. New York: Chandler Publishing Company.

Jackson, $\mathrm{D}$ and $\mathrm{R}$ Jackson 2009. A comparative introduction to politics. Toronto: Prentice Hall.

Johnson, RW 2004. South Africa: The first man, the last nation. Cape Town: Jonathan Ball.

Koorts, L 2013. DF Malan en die opkoms van Afrikaner nasionalisme. Kaapstad: Tafelberg Uitgewers.

Kotzé, H and J van Wyk 1988. Politieke konsepte. Pretoria: Academica.

Laqueur, W 1973. A dictionary of politics. London: Pan Books.

McHenry, DE 2008. "The origins of caucus selection of cabinet", Historical Studies 7(1):37-43.

Millar, Peter 2015. Interview, 5 July, as DA Caucus Chairperson.

Parliament of Uganda s.a. "MPs want independence from party caucuses", <www.parliament.go.ug/.../877-mps-want-independence-from-party-caucuses>, accessed 1 December 2016

Pinney, N and G Serra 1999. "The Congressional Black Caucus and vote cohesion: Placing the caucus within house voting patterns", Political Research Quarterly 52(3):583-608. https://doi.org/10.2307/449150

Roberts, GK 1971. A dictionary of political analysis. London: Longman.

South African Institute of Race Relations (SAIRR) 2016. South Africa survey 2014/2015. Johannesburg: SAIRR.

Strong, CF 1966. Modern political constitutions. London: Sidgwick \& Jackson.

Talbot, JC 1998. "Congressional caucuses in national policy making", Political Sciences Quarterly 113(2):326-327. https://doi.org/10.2307/2657869

The British Parliament 1968. London: Her Majesty's Stationery Office. 
The free dictionary s.a. "Caucus", <www.thefreedictionary.com.causus>, accessed 5 December 2016.

The Guardian 2016. "Labour leadership contest. What are the rules?", 10 July, <www.theguardian.com/.../10/labours-leadership...do-the-rules-look-like>, accessed 5 December 2016.

Thompson, L and A Prior 1982. South African politics. Cape Town: David Philip. https://doi.org/10.2307/j.ctt1ww3vc0

United States House of Representatives s.a. "Committees and caucuses. United States House of Representatives", <http://capuano.house.gov/issues/ committees. shtml>, accessed 22 August 2016.

Venter, A 1989. South African government and politics: An introduction to its institutions, processes and policies. Johannesburg: Southern Book Publishers.

Venter, A and A Johnston (eds) 1991. Politics: An introduction for Southern African students. Cape Town: Oxford University Press.

Webb, P 2008. "The attitudinal assimilation of Europe by the Conservative Parliamentary Party", British Politics 4:427-444. https://doi.org/10.1057/ bp.2008.24

Wiechers, M 1985. 'n Politieke idiotikon vir Suid-Afrika. Kaapstad: Tafelberg.

Zille, H 2016. Not without a fight: The autobiography. Cape Town: Penguin. 